\title{
Nogo Receptor 1 Confines a Disinhibitory Microcircuit to the Critical Period in Visual Cortex
}

\author{
(10Céleste-Élise Stephany, ${ }^{1 *}$-Taruna Ikrar, ${ }^{2 \star}$ Collins Nguyen, ${ }^{2}$ Xiangmin $\mathrm{Xu},{ }^{2}$ and ${ }^{\circledR}$ Aaron W. McGee ${ }^{1}$ \\ ${ }^{1}$ Developmental Neuroscience Program, Saban Research Institute, Children's Hospital Los Angeles, Department of Pediatrics, Keck School of Medicine, \\ University of Southern California, Los Angeles, California 90027, and 2Department of Anatomy and Neurobiology, School of Medicine, University of \\ California, Irvine, California 92697
}

A characteristic of the developing mammalian visual system is a brief interval of plasticity, termed the "critical period," when the circuitry of primary visual cortex is most sensitive to perturbation of visual experience. Depriving one eye of vision (monocular deprivation [MD]) during the critical period alters ocular dominance (OD) by shifting the responsiveness of neurons in visual cortex to favor the nondeprived eye. A disinhibitory microcircuit involving parvalbumin-expressing (PV) interneurons initiates this OD plasticity. The gene encoding the neuronal nogo-66-receptor 1 ( ngr 1/rtn4r) is required to close the critical period. Here we combined mouse genetics, electrophysiology, and circuit mapping with laser-scanning photostimulation to investigate whether disinhibition is confined to the critical period by ngrl. We demonstrate that $n g r 1$ mutant mice retain plasticity characteristic of the critical period as adults, and that ngrl operates within PV interneurons to restrict the loss of intracortical excitatory synaptic input following MD in adult mice, and this disinhibition induces a "lower PV network configuration" in both critical-period wild-type mice and adult $n g r 1^{-1-}$ mice. We propose that $n g r l$ limits disinhibition to close the critical period for OD plasticity and that a decrease in PV expression levels reports the diminished recent cumulative activity of these interneurons.

Key words: disinhibition; interneuron; ocular dominance; parvalbumin; plasticity

\section{Significance Statement}

Life experience refines brain circuits throughout development during specified critical periods. Abnormal experience during these critical periods can yield enduring maladaptive changes in neural circuits that impair brain function. In the developing visual system, visual deprivation early in life can result in amblyopia (lazy-eye), a prevalent childhood disorder comprising permanent deficits in spatial vision. Here we identify that the nogo-66 receptor 1 gene restricts an early and essential step in 0D plasticity to the critical period. These findings link the emerging circuit-level description of OD plasticity to the genetic regulation of the critical period. Understanding how plasticity is confined to critical periods may provide clues how to better treat amblyopia.

\section{Introduction}

The developing circuitry of the mammalian visual system is instructed by experience during an early critical period (Levelt and

Received March 21, 2016; revised Aug. 16, 2016; accepted Sept. 2, 2016.

Author contributions: X.X. and A.W.M. designed research; C.-E.S., T.I., and C.N. performed research; X.X. and A.W.M. contributed unpublished reagents/analytic tools; C.-E.S., T.I., C.N., X.X., and A.W.M. analyzed data; C.-E.S., X.X., and A.W.M. wrote the paper.

This work was supported by the National Eye Institute 1R01EY021580 and Children's Hospital Los Angeles Research Development Career Award to A.W.M., and in part by National Institutes of Health Grants NSO78434 and MH105427 to X.X. C.-E.S. received a Saban Research Institute predoctoral fellowship. A.W.M. received a Burroughs Wellcome Fund Career Award in the Biomedical Sciences.

The authors declare no competing financial interests.

${ }^{*}$ C.-E.S. and T.I. contributed equally to this work.

Correspondence should be addressed to either of the following: Dr. Xiangmin Xu, Department of Anatomy and Neurobiology, School of Medicine, University of California, Irvine, CA 92697, E-mail: xiangmix@uci.edu; or Dr. Aaron W. McGee, Department of Anatomical Sciences \& Neurobiology, University of Louisville, Louisville, KY 40292. E-mail: aaron.mcgee@louisville.edu.

A.W. McGee's present address: Department of Anatomical Sciences and Neurobiology, University of Louisville, Louisville, KY 40202
Hübener, 2012). Abnormal experience, such as brief monocular deprivation (MD), within the critical period, but not thereafter, alters the ocular dominance (OD) of neurons in primary visual cortex (Wiesel and Hubel, 1963; Hubel and Wiesel, 1970; Gordon and Stryker, 1996). In the mouse, this critical period extends from the third week $(\sim$ P19) to the fifth week $(\sim$ P32) postnatal. Four or more days of MD during this interval yields saturating shifts in OD toward the nondeprived eye. In adult mice, longer periods of deprivation are required to shift OD (Sawtell et al., 2003; Fischer et al., 2007a; Morishita and Hensch, 2008; Sato and Stryker, 2008). The OD plasticity in adult mice is smaller in magnitude than during the critical period and operates through distinct mechanisms. Studies using a range of experimental techniques reveal that OD plasticity engages both excitatory and inhibitory 
neurons in visual cortex (Taha et al., 2002; Gandhi et al., 2008; Stephany et al., 2014).

Mice lacking a functional gene for the nogo-66 receptor 1 (ngr1) retain critical-period OD plasticity as adults. Adult ngr1 constitutive mutants $\left(n g r 1^{-/-}\right)$display OD plasticity with $4 \mathrm{~d}$ of $\mathrm{MD}$ at P60 indistinguishable from wild-type (WT) mice at P24 (McGee et al., 2005; Stephany et al., 2014, 2015). The speed, magnitude, and sensitivity to anesthetics of OD plasticity of adult $n g r 1^{-1-}$ mice mirror that of WT mice during the critical period (Pham et al., 2004; McGee et al., 2005; Fischer et al., 2007b). A decrease in the ratio of excitatory to inhibitory neurotransmission (E/I balance) also coincides with the closure of the critical period (Morales et al., 2002). Adult $n g r 1^{-/-}$mice exhibit slightly lower cortical inhibition resulting from a modest reduction in excitatory drive onto parvalbumin (PV)-expressing interneurons (Stephany et al., 2014). This higher E/I balance manifests as a lower frequency but not amplitude of spontaneous EPSCs onto PV inhibitory neurons and spontaneous IPSCs onto nearby pyramidal excitatory neurons. Critical period OD plasticity is also unaffected by diazepam (DZ), a positive allosteric modulator of the gamma-aminobutyric acid receptor A (GABA-A) (Hensch et al., 1998).

Disinhibition initiates OD plasticity (Kuhlman et al., 2013). One day of MD during the critical period elevates the visually evoked activity of cortical excitatory neurons in alert mice. This increase in visual responsiveness results from a reduction in activity by fast-spiking PV-positive interneurons that in turn can be attributed to a decrease in local excitatory synaptic drive onto these inhibitory neurons. Importantly, this disinhibition precedes shifts in OD and appears to be permissive rather than instructive for subsequent OD plasticity. How this disinhibitory microcircuit is confined to the critical period is not yet known.

Here we investigated whether ngrl may contribute to closing the critical period by reducing E/I balance and/or by restricting disinhibition (Morales et al., 2002; Morishita and Hensch, 2008; Kuhlman et al., 2013). We demonstrate that OD plasticity in constitutive $n g r 1^{-/-}$adults is resistant to treatment with DZ, both adult $n g r 1^{-1-}$ mice and adult mice lacking $n g r 1$ selectively in PV interneurons $\left(n g r 1^{f l x / f l x} ; P V-C r e\right)$ display a decrease in excitatory drive onto PV interneurons with $1 \mathrm{~d}$ MD that is confined to the critical period in WT mice, and that a lower relative distribution of PV expression by interneurons reports this disinhibition within visual cortex in both juvenile WT mice and adult n $g r 1^{-1-}$ mice. These findings support the model that $n g r 1$ closes the critical period by preventing the loss of excitatory synapses onto PV interneurons during MD.

\section{Materials and Methods}

All procedures and care were performed in accordance with the guidelines of the Institutional Animal Care and Use Committees at Children's Hospital Los Angeles and the University of California, Irvine.

Mice. Constitutive $n g r 1^{-1-}$ mutant mice and the conditional $n g r 1^{f l x / f l x}$ mutant mice were a generous gift from Dr. Stephen Strittmatter, Yale University School of Medicine (Kim et al., 2004; Wang et al., 2011). Mutant mice were repeatedly backcrossed onto the C57BL6 background to at least F8. To identify PV interneurons for laser scanning photostimulation (LSPS) experiments, we examined WT and ngrl mutant mice that carried alleles for the Cre-dependent td-Tomato reporter (Ai14) and PV-Cre (Hippenmeyer et al., 2005; Madisen et al., 2010). The Ail4 reporter and PV-Cre driver lines were both obtained from Jackson Laboratories (strain \#007908 and \#0017320, respectively). Genotyping was performed using custom primer sets for PCR amplification. Experiments were performed on both male and female mice.
$M D$. One eye was closed using a single mattress suture tied with 6-0 polypropylene monofilament (Prolene $8709 \mathrm{H}$; Ethicon) under brief isoflurane anesthesia $(2 \%)$. The knot was sealed with cyanoacrylate glue. The duration of eye closure was either $4 \mathrm{~d}$ before multiunit electrophysiology (4 d MD), or $1 \mathrm{~d}$ before laser scanning photostimulation or perfusion for immunostaining ( $1 \mathrm{~d} \mathrm{MD})$. Before electrophysiologic recordings, the suture was removed, and the eye was flushed with sterile saline and examined under a stereomicroscope. Mice with scarring of the cornea were eliminated from the study.

DZ treatment. A subset of juvenile WT mice (P24-P28) and adult $n g r 1^{-/-}$mice (P60-P90) were administered DZ (2 mg/kg) or saline by daily intraperitoneal injection, concurrent with $4 \mathrm{~d} \mathrm{MD}$ before multiunit electrophysiology (Deidda et al., 2015).

Electrophysiologic recordings in visual cortex. Recording methods were adapted from previously published methods (McGee et al., 2005; Stephany et al., 2014) and mice were anesthetized with isoflurane (4\% induction, 2\% maintenance in $\mathrm{O}_{2}$ ) rather than barbiturates (Nembutal) as we have used in preceding studies. Recordings were performed blind to genotype and drug treatment.

The ocular dominance index (ODI) was calculated for each unit by comparing the number of action potentials (APs) elicited in a given unit when showing the same visual stimulus to each eye independently. Units were assigned to one of seven OD categories (1-7). Units assigned to category 1 respond predominantly to input from the contralateral eye, and units assigned to category 7 respond predominantly to input from the ipsilateral eye (Wiesel and Hubel, 1963). To categorize each unit, the average number of APs elicited by the blank was subtracted from the average number of APs elicited by the gratings for the contralateral eye (CE) and the ipsilateral eye (IE). Next, the ODI, given by ODI = (IE $\mathrm{CE}) /(\mathrm{IE}+\mathrm{CE})$ was calculated for each unit and assigned to OD categories $1-7$ as follows: $1,-1$ to $-0.6 ; 2,-0.6$ to $-0.4 ; 3,-0.4$ to $-0.1 ; 4$, -0.1 to $0.1 ; 5,0.1-0.4 ; 6,0.4-0.6$; and $7,0.6-1$. Finally, the sum of the number of cells in each category was used to calculate the contralateral bias index $(\mathrm{CBI})$ for each animal with the following formula: $\mathrm{CBI}=$ $\left[\left(n_{1}-n_{7}\right)+(2 / 3)\left(n_{2}-n_{6}\right)+(1 / 3)\left(n_{3}-n_{5}\right)+N\right] / 2 N$ where $N$ is the total number of units and $n_{\mathrm{x}}$ is the number of units with OD scores equal to $x$ (Gordon and Stryker, 1996).

LSPS for circuit mapping. Electrophysiological recordings and photostimulation were performed as described previously (Xu et al., 2010). Electrophysiological data were acquired with a Multiclamp 700B amplifier (Molecular Devices), data acquisition boards (models PCI MIO16E-4 and 6713, National Instruments), and custom-modified version of Ephus software34 (Ephus; https://openwiki.janelia.org/). Data were digitized at $10 \mathrm{kHz}$.

The LSPS procedures were similar to those described previously (Weiler et al., 2008; Kuhlman et al., 2013). LSPS was performed through a $4 \times$ objective lens. Stock solution of MNI-caged-L-glutamate (Tocris Bioscience) was added to $20 \mathrm{ml}$ ACSF for a concentration of $0.2 \mathrm{~mm}$ caged glutamate. The cortical slice image, acquired through the $4 \times$ objective, was visualized using a high-resolution digital CCD camera, and this image, in turn, was used to guide and register photostimulation sites. An electro-optical modulator and a mechanical shutter controlled the delivery of $1.5 \mathrm{~ms}$ duration, $15 \mathrm{~mW}$ pulses from a $350 \mathrm{~nm}$ UV laser (DPSS Lasers) to the slice. Focal laser spots approximated a Gaussian profile with a lateral width of 50-100 $\mu \mathrm{m}$. Under our experimental conditions, LSPS-evoked APs were recorded from stimulation locations within 100 $\mu \mathrm{m}$ of targeted excitatory neuronal somata and occurred within $150 \mathrm{~ms}$ after photostimulation. This indicates that LSPS has a sufficient resolution for V1 laminar circuit mapping. LSPS-evoked EPSCs in patched neurons were detected under voltage clamp at an empirically determined membrane potential of $-70 \mathrm{mV}$. By systematically surveying synaptic inputs from hundreds of different sites across a large cortical region, aggregate synaptic input maps were generated for individual neurons. For our mapping experiments, a standard stimulus grid $(16 \times 16$ stimulation sites, $65 \mu \mathrm{m}^{2}$ spacing) was used to tessellate V1 from pia to white matter. The LSPS site spacing was empirically determined to capture the smallest predicted distance in which photostimulation differentially activates adjacent neurons. Glutamate uncaging was delivered sequentially in a nonraster, nonrandom sequence, following a "shifting- $X$ " pattern 
designed to avoid revisiting the vicinity of recently stimulated sites (Shepherd et al., 2003).

Laminar circuit input analysis. Photostimulation induces two forms of excitatory responses: (1) those that result from direct activation of the recorded neuron's glutamate receptors; and (2) synaptic responses (EPSCs) resulting from the suprathreshold activation of presynaptic excitatory neurons (see Fig. $2 A-C$ ). Responses that occur within $10 \mathrm{~ms}$ of laser pulse onset were considered direct; these responses exhibited a distinct shape and occurred immediately after glutamate uncaging. Synaptic currents with such short latencies are not possible because they would have to occur before the generation of APs in photostimulated neurons. Therefore, direct responses were excluded from local synaptic input analysis. At some locations, synaptic responses were overriding on relatively small direct responses; such responses were identified and included in synaptic input analysis as described previously (Kuhlman et al., 2013). To check for any systematic differences across treatment conditions, the spatial extent and frequency of APs elicited in response to direct photostimulation were determined in a subset of the experiments by performing whole-cell recordings in current-clamp mode using an $8 \times 8$ mapping grid. Photostimulation excitation profiles assessed by glutamate uncaging were found to be similar for control and MD.

For data map analysis, LSPS-evoked EPSCs were quantified across the $16 \times 16$ mapping grid for each cell, and 2-4 individual maps were averaged per recorded cell, reducing the likelihood of incorporating noise events in the analysis window ( $150 \mathrm{~ms}$ ). Averaged maps were then analyzed using the $4 \times$ DIC image to bin responses according to laminar cytoarchitectonic landmarks. Synaptic events were binned from locations spanning $\pm 195 \mu \mathrm{m}$ tangential to the targeted soma location and from the top of layer $2 / 3$ to the bottom of layer 6 across the radial vector. Data were plotted as the average integrated EPSC amplitude per map location.

Immunohistochemistry. Mice were deeply anesthetized with ketamine $\mathrm{HCl}$ (200 mg/kg, Phoenix Pharmaceuticals)/xylazine $(20 \mathrm{mg} / \mathrm{kg}$, Lloyd Laboratories) and transcardially perfused with PBS (ChemCruz, SC362299) followed by a buffered 4\% PFA/PBS (Acros Organics, $416780030)$. Brains were postfixed overnight in $4 \%$ PFA/PBS. Freefloating $50 \mu \mathrm{m}$ sections were cut on a vibrating microtome (Leica, VT $1000 S$ ) in cool PBS and preserved in PBS containing $0.05 \%$ sodium azide (Sigma-Aldrich, S8032).

Coronal sections containing visual cortex were washed in PBS $(3 \times 5$ $\mathrm{min}$ ) and incubated in blocking solution, 3\% normal donkey serum (Jackson ImmunoResearch Laboratories) in PBS containing 0.1\% Triton X-100 (Sigma-Aldrich T9284) (PBS-T) for $1 \mathrm{~h}$ at room temperature. The primary antibody sheep anti-PV (R\&D Systems, AF5058) was diluted in blocking solution to $1 \mu \mathrm{g} / \mathrm{ml}$ and sections incubated in primary antibody overnight at $4^{\circ} \mathrm{C}$. After repeated washing in PBS-T $(3 \times 30 \mathrm{~min})$, sections were incubated in Alexa-488-conjugated secondary antibody (Jackson ImmunoResearch Laboratories, 1:200 in blocking solution) overnight at $4^{\circ} \mathrm{C}$. The first among a final series of washes contained Hoechst $(1: 10,000$ in PBS-T, Santa Cruz Biotechnology) $(1 \times 10 \mathrm{~min})$, followed by PBS-T $(2 \times 30 \mathrm{~min})$ and PBS $(1 \times 10 \mathrm{~min})$. Sections were mounted onto SuperFrost Plus slides (Fisher Scientific) with SlowFade Gold anti-fade reagent (Invitrogen).

Analysis of PV cell intensity. Analysis of PV cell intensity was adapted from previous reports (Donato et al., 2013). Images from coronal sections stained with anti-PV were captured with an LSM-710 confocal microscope with a $20 \times 0.4$ NA objective (Zeiss). Hoechst staining was used to demarcate visual cortex before capturing images of PV cells. The acquisition settings (laser intensity and gain) were identical for all sections processed in parallel throughout each set of experiments. For each series, sections from a nondeprived WT mouse (P60) were used to optimize the settings, maximizing the dynamic range while ensuring that no more than $20 \%$ of pixels within any PV cell were saturated. An internal standard was processed as described during each series. Two images were required to span the distance from the subcortical white matter to the pial surface. Images were merged in Fiji using the 3D stitching macro. Sections with dampening $>30 \%$ between the first and last confocal plane were excluded from further analysis.

The intensity of each PV cell whose somas were completely contained in the slice of tissue was obtained using IMARIS software (8.0.0, Bit- plane). Three-dimensional spheres with a diameter of $7.5 \mu \mathrm{m}$ were drawn around the center of each PV cell (smoothness, $0.5 \mu \mathrm{m}$; quality, $>175$ ). Spheres of consistent diameter were used rather than isosurfaces to eliminate errors introduced by the point spread function in the $Z$-plane. The intensity of immunohistochemical PV labeling was quantified as the average pixel intensity in arbitrary units (au) of pixels contained in the $7.5 \mu \mathrm{m}$ sphere. PV neurons were classified into four categories by their average intensity: low PV $(<1300 \mathrm{au})$, mid-low PV (1300-2200 au), mid-high PV (2200-3100 au), and high PV (>3100 au).

Statistical analysis. All statistical analyses were performed using Prism software (version 6.0, GraphPad). Unless otherwise stated, group comparisons were made using unpaired, nonparametric Mann-Whitney tests. Where multiple groups are compared, one-way nonparametric ANOVA was used (Kruskal-Wallis test with Dunn's multiple comparisons test). Error bars indicate \pm SEM.

\section{Results}

First, to test whether the moderate increase in E/I balance displayed by adult $n g r 1^{-1-}$ mice contributes to the sustained critical period for OD plasticity, we augmented cortical inhibition with DZ. DZ elevates cortical inhibition to open a precocious critical period in juvenile WT mice but does not block OD plasticity during the critical period as measured with single-unit recordings (Hensch et al., 1998). We treated juvenile WT and adult $n g r 1^{-1-}$ mice with saline or DZ daily during $4 \mathrm{~d}$ of MD preceding electrophysiologic recording $(2 \mathrm{mg} / \mathrm{kg} / \mathrm{d}$ ) (Fig. $1 \mathrm{~A}, E)$. DZ did not block OD plasticity for WT mice during the critical period or $n g r 1$ mutants at P60, as mice receiving either DZ or saline displayed rightward shifts toward the nondeprived eye in OD histograms (Fig. $1 B, F$ ), decreased CBI scores (Fig. 1C,G; WT CP vs WT CP $4 \mathrm{~d} \mathrm{MD}+$ saline, $p=0.01$; WT CP vs WT CP $4 \mathrm{~d} \mathrm{MD}+\mathrm{DZ}, p=$ $0.005 ; \mathrm{KO}$ vs $\mathrm{KO} 4 \mathrm{~d} \mathrm{MD}+$ saline, $p=0.02 ; \mathrm{KO}$ vs $\mathrm{KO} 4 \mathrm{~d}$ $\mathrm{MD}+\mathrm{DZ}, p=0.02$ ), and rightward shifts in the cumulative distribution of OD scores for individual units relative to nondeprived controls (Fig. $1 D, H$ ). This finding is consistent with $n g r 1^{-1-}$ mice retaining critical-period visual plasticity that is mechanistically distinct from the slower and more limited visual plasticity resident in the adult visual system (Hensch et al., 1998; Sawtell et al., 2003; Pham et al., 2004; Fischer et al., 2007a; Harauzov et al., 2010).

Second, we examined whether the circuit plasticity for disinhibition is sustained in adult WT or $n g r 1^{-/-}$mice. During the critical period, $1 \mathrm{~d}$ of MD reduces excitatory synaptic input onto $\mathrm{PV}$ interneurons to induce a pronounced disinhibition of visual responsiveness (Kuhlman et al., 2013). We used LSPS to assess the spatial distribution and total strength of synaptic inputs onto $\mathrm{PV}$ interneurons in visual cortex of adult WT and $n g r 1^{-1-}$ mice (Fig. 2A-C). To identify PV interneurons, we used a Credependent td-Tomato reporter strain (Ai14) in combination with PV-Cre (Hippenmeyer et al., 2005; Madisen et al., 2010). In adult WT mice, $1 \mathrm{~d}$ of MD did not appreciably alter the excitatory synaptic input onto layer (L) 2/3 PV interneurons, and the total synaptic current was not different between nondeprived animals and those receiving MD (Fig. $2 D-F$ ). Thus, disinhibition with $\mathrm{MD}$ is confined to the critical period.

Conversely, in adult $n g r 1^{-1-}$ mice, $1 \mathrm{~d}$ of MD significantly reduced the magnitude of LSPS-induced EPSCs onto L2/L3 PV neurons compared with WT mice and nondeprived $n g r 1^{-1-}$ mice ( $p=0.001$ and $p=0.03$, respectively; Fig. $2 E)$. L2/L3, L4, and L5 provide excitatory synaptic input onto L2/L3 PV interneurons in visual cortex (Kuhlman et al., 2013). We compared the strength of synaptic input across cortical layers between adult WT and $n g r 1^{-1-}$ mice, with and without $1 \mathrm{~d}$ of MD (Fig. $2 F$ ). The reduction of total synaptic current in adult $n g r 1^{-/-}$mice follow- 

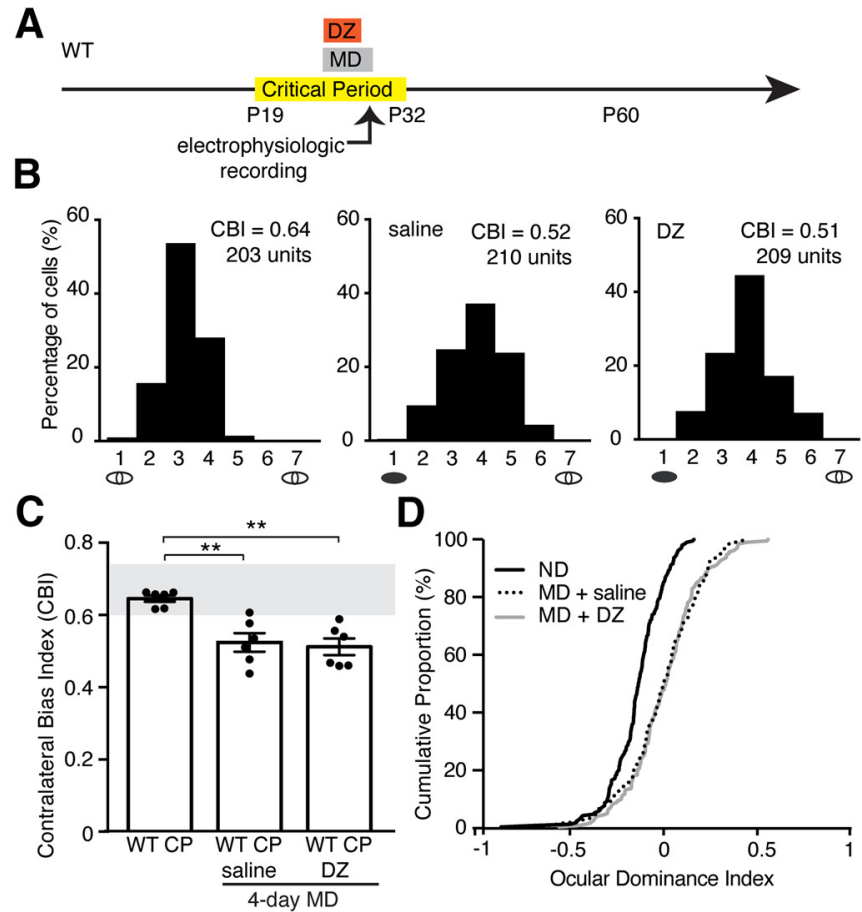

D

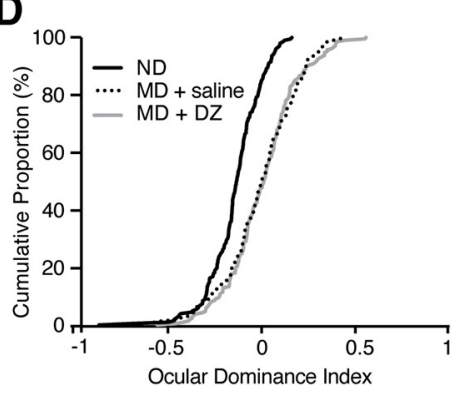

E

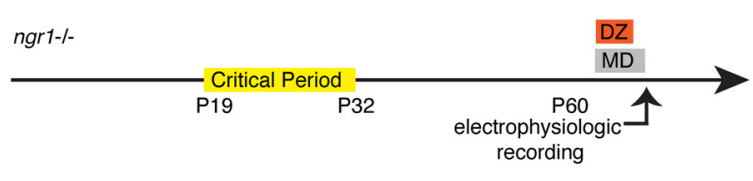

$\mathbf{F}$

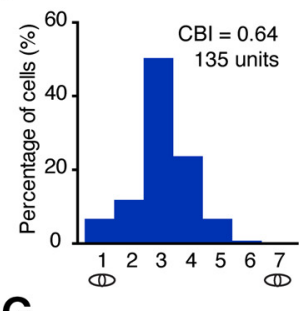

G
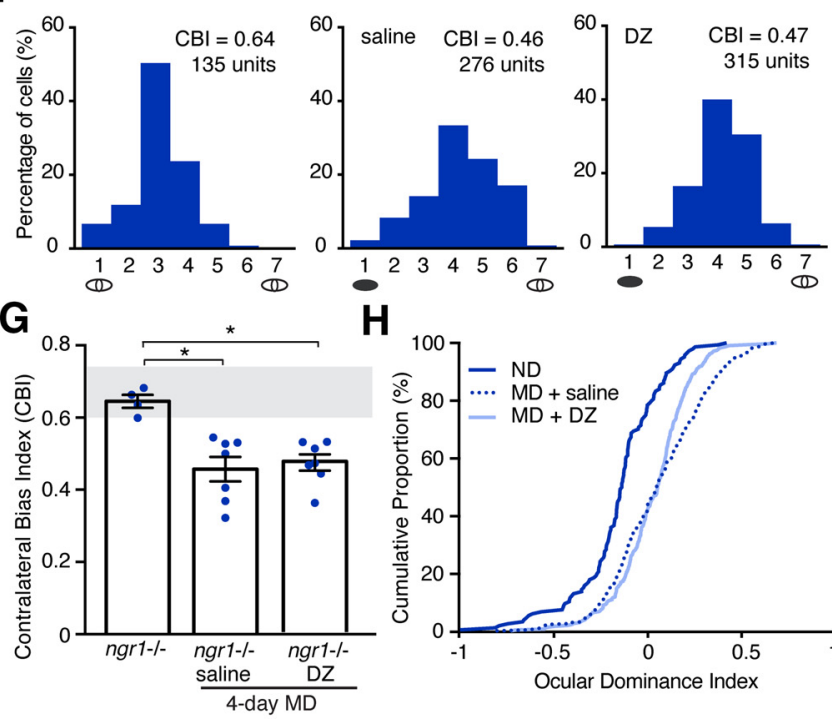

H

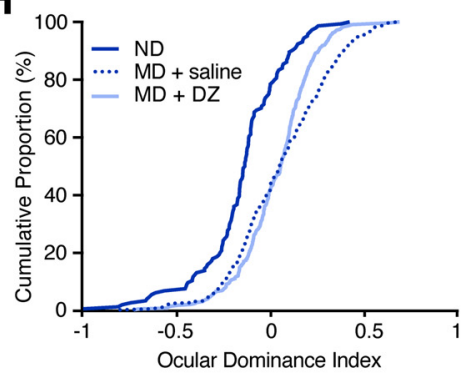

Figure 1. Increasing use-dependent GABA-A neurotransmission with DZ does not block OD plasticity in critical period and $n g r 1^{-/-}$mice. $A$, Schematic of the timeline for DZ injection and MD before assessment of OD in WT critical period (WT CP) mice (black). B, OD histograms and CBI score for nondeprived WT CP mice $(n=6)$, and WT CP mice receiving $4 \mathrm{~d} \mathrm{of} \mathrm{MD} \mathrm{(} 4 \mathrm{~d}$ MD) concurrent with saline injection $(n=6)$ or DZ injection ( $n=6$ ). A black ellipse under the histogram indicates MD. There is a rightward shift toward the open eye in OD histograms for WT CP mice receiving saline or DZ injection with $4 \mathrm{~d} \mathrm{MD}$. C, The median CBI score for WT CP mice is lower after $4 \mathrm{~d} \mathrm{MD} \mathrm{concurrent} \mathrm{with} \mathrm{daily} \mathrm{DZ} \mathrm{or} \mathrm{saline} \mathrm{injection} \mathrm{(i.p.)} \mathrm{compared} \mathrm{with} \mathrm{nondeprived} \mathrm{controls.} \mathrm{Each} \mathrm{point} \mathrm{indicates} \mathrm{the}$ CBI for an individual animal. Bars represent the average for each group. Error bars indicate SEM. Gray box represents the typical range of CBI scores for nondeprived mice. $D$, Cumulative histograms of OD scores for groups reported in $\boldsymbol{B}, \boldsymbol{C}$. $\boldsymbol{E}-\boldsymbol{H}$, Same as $\boldsymbol{A}-\boldsymbol{D}$ for adult (P60) $n g r 1^{-1-}$ mice (blue). $\boldsymbol{F}$, Nondeprived $(n=4) ; 4 \mathrm{~d} \mathrm{MD}+$ saline $(n=7) ; 4 \mathrm{~d} \mathrm{MD}+\mathrm{DZ}(n=7)$. G, The median (BI score for $n g r 1^{-1-}$ mice is lower after $4 \mathrm{~d} \mathrm{MD}$ concurrent with daily $\mathrm{DZ}$ or saline injection (i.p.) compared with nondeprived controls. ${ }^{*} p<0.05$; ${ }^{* *} p<0.01$.

ing $1 \mathrm{~d}$ of MD was a result of significantly decreased synaptic input across these layers. The average strength of excitatory synaptic drive was greater for nondeprived WT mice relative to WT mice following $1 \mathrm{~d}$ MD in L5, but this difference was not statistically significant ( $p=0.55$ ), whereas $1 \mathrm{~d}$ MD reduced total synaptic current from L2/L3, L4, and L5 (ngr1 ${ }^{-/-}$vs $n g r 1^{-1-} 1 \mathrm{~d}$ $\mathrm{MD}, p=0.05, p=0.02$, and $p=0.01$, respectively). We conclude that $n g r l$ functions to restrict the loss of excitatory synaptic input onto PV interneurons with MD in adult animals.

Third, to explore where NgR1 functions within cortical circuits to limit the reduction of synaptic drive onto PV interneurons by $\mathrm{MD}$, we examined mice lacking ngrl selectively in PV interneurons. Deleting ngrl either in the majority of cortical inhibitory neurons with Dlx5/6-Cre, or in PV interneurons with PV-Cre, sustains critical-period OD plasticity in adult mice (Stephany et al., 2014). Similar to adult $n g r 1^{-1-}$ mice, $1 \mathrm{~d}$ of MD also significantly reduced the magnitude of LSPS-induced EPSCs onto L2/L3 PV neurons in mice lacking $n g r 1$ in PV interneurons $(p=0.0005)$ (Fig. 3). Therefore, NgR1 can operate within PV interneurons to limit the loss of excitatory intracortical synaptic input associated with critical-period OD plasticity.

Last, we tested whether the dramatic decrease in synaptic input onto PV interneurons following $1 \mathrm{~d}$ of MD alters the overall PV network in visual cortex. Recent studies have reported that the intensity of PV immunoreactivity reflects the relative strength of inhibitory circuitry. PV expression correlates with GAD67 expression, interneurons with low PV expression display lower ratios of excitatory to inhibitory synaptic density, and this "low-PV configuration" is associated with enhanced learning and structural plasticity (Donato et al., 2013). In hippocampus, motor cortex, and somatosensory cortex, the distribution of PV expression is both developmentally regulated and experiencedependent (Donato et al., 2013, 2015). However, whether this enhanced learning is accompanied by alterations in the spiking activity of excitatory or inhibitory neurons has not been determined. Given that $1 \mathrm{~d} \mathrm{MD}$ during the critical period decreases the firing rate of PV neurons in vivo (Kuhlman et al., 2013), we assessed whether the distribution of PV immunoreactivity reflects disinhibition associated with critical-period visual plasticity.

We measured the intensity of PV immunoreactivity across populations of $\mathrm{PV}$ interneurons in the binocular zone of primary visual cortex in WT mice and $n g r 1^{-1-}$ mice at different ages (Fig. $4 A)$. We subdivided the population of interneurons into categories of PV intensity: low, mid-low, mid-high, and high (Fig. $4 A, B)$ (Donato et al., 2013). The percentage of interneurons in the low category decreases from P20 to P60 across all cortical layers (Fig. 4C). However, there was no difference in the distribution of PV immunoreactivity intensity between adult nondeprived WT and $n g r 1^{-1-}$ mice despite the modest decrease in total synaptic input onto L2/L3 PV interneurons in ngrl mutants (Fig. $4 D$ ). One day of MD in juvenile WT mice (P24) significantly decreased the percentage of interneurons with high PV immunoreactivity ( $p=0.018$ ) (Fig. $4 E, F)$. Similarly, $1 \mathrm{~d}$ of MD in adult (P60) ngr ${ }^{-1-}$ mice also yielded a significant decrease in the percentage of interneurons with high PV immunoreactivity $(p=$ 0.004). This shift in PV network configuration was accompanied by an increase in the proportion of interneurons with low PV expression (Fig. 4F). However, $1 \mathrm{~d}$ MD did not alter the distribution of PV immunoreactivity intensity in adult WT mice. Thus, $\mathrm{PV}$ expression levels reflect the recent cumulative activity of PV 
A

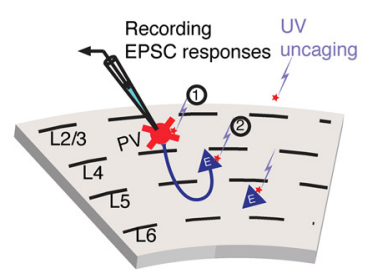

D
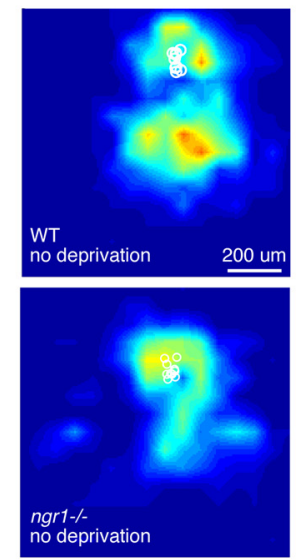

B

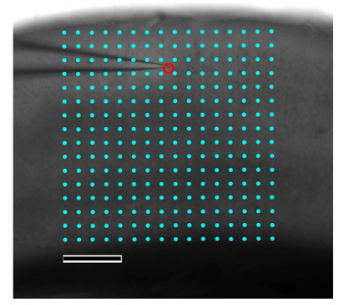

E
C

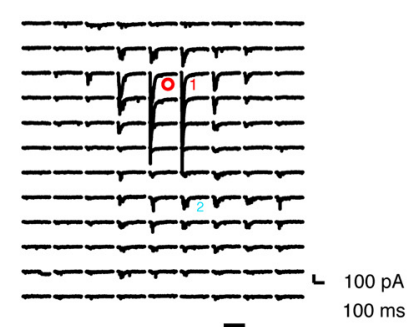

F
UV $1.5 \mathrm{~ms}$

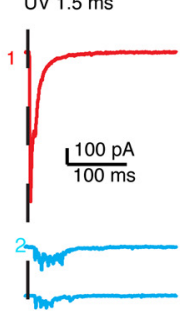

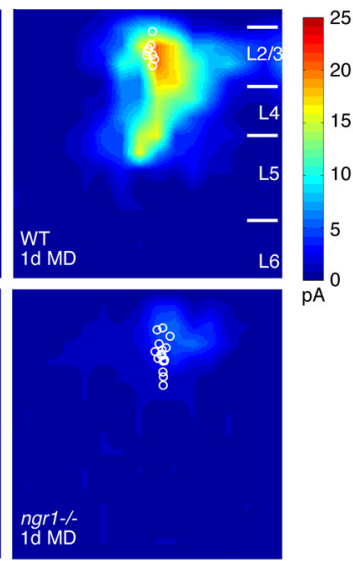

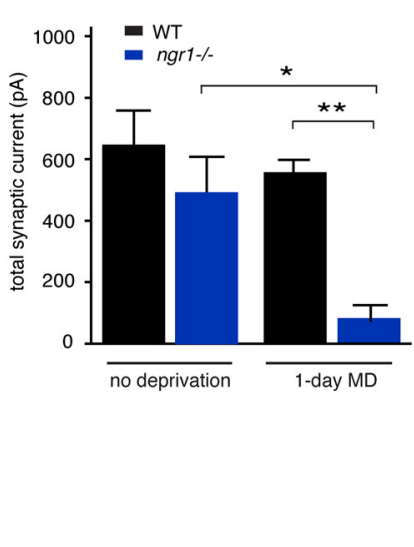

Figure 2. NgR1 restricts disinhibition to the critical period. $A$, A schematic of the recording configuration. PV interneurons are patched in the whole-cell configuration while UV laser directs the focal release of glutamate over the soma of excitatory neurons distributed throughout the tissue section. Glutamate uncaging drives the firing of APs by neurons under the region of brief UV illumination. $\boldsymbol{B}$, An example of the $16 \times 16$ grid (aqua dots) and the position of a recorded PV interneuron on L2/L3 (red circle). $C$, An example of (1) the current induced by direct somatic stimulation of the recorded PV interneuron and (2) excitatory synaptic currents. D, LSPS mapping of excitatory synaptic inputs onto PV interneurons in L2/L3 of adult (P55-P65) WT and ngr $1^{-/-}$mice (WT, $n=$ $\left.13 ; \mathrm{WT} 1 \mathrm{~d} \mathrm{MD}, n=9 ; n g r 1^{-1-}, n=9 ; n g r 1^{-1-} 1 \mathrm{dMD}, n=16\right)$. Adult $n g r 1^{-1-}$ mice display a loss of excitatory drive with $1 \mathrm{~d}$ MD similar to WT mice during the critical period. $\boldsymbol{E}$, Quantification of total synaptic input for WT and $n g r 1^{-1-}$ mice with and without $1 \mathrm{~d} \mathrm{MD} .{ }^{*} p=0.03$. ${ }^{* *} p=0.0007$. F, Comparison of the laminar distribution of average excitatory synaptic input to L2/L3 PV interneurons across genotypes and conditions. Data are mean \pm SE. Black bar represents WT. Gray bar represents WT $+1 \mathrm{~d}$ MD. Dark blue bar represents $n g r 1^{-/-}$without MD. Light blue bar represents $n g r 1^{-\prime-}+1 \mathrm{~d}$ MD. ${ }^{*} p<0.05 .{ }^{* *} p<.01$.
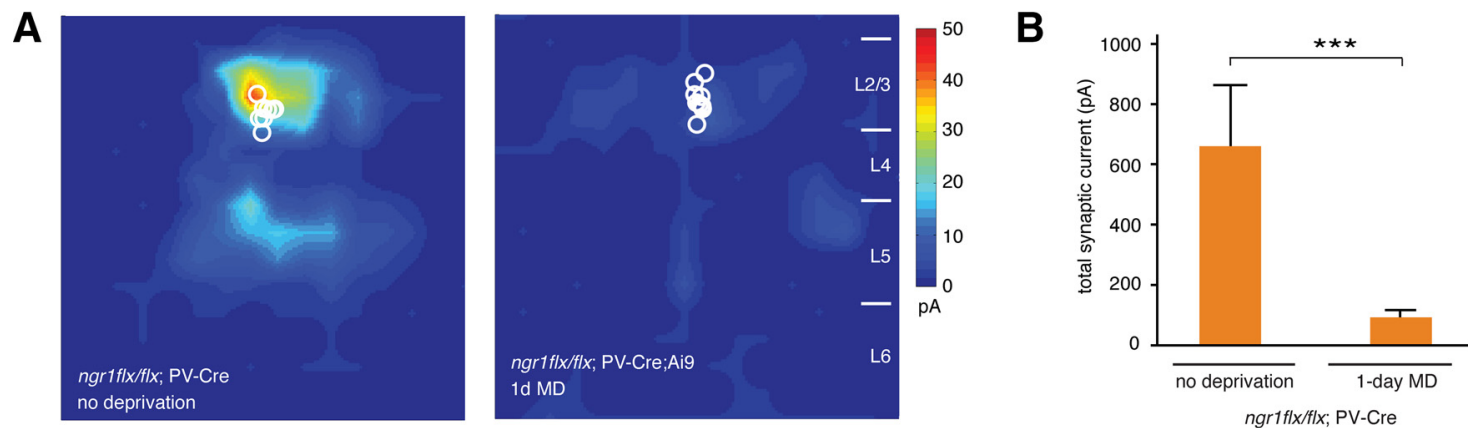

Figure 3. $\mathrm{NgR} 1$ operates in PV interneurons to limit disinhibition following $1 \mathrm{~d}$ MD. A, LSPS mapping of excitatory synaptic inputs onto PV interneurons in L2/L3 of nondeprived adult (P55-P85)

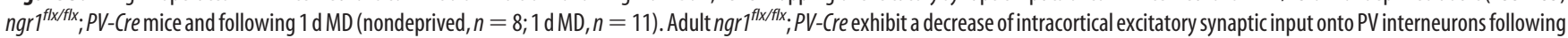
$1 \mathrm{~d} \mathrm{MD}$ similar to adult $n g r 1^{-1-}$ mice. $B$, Quantification of total synaptic input for nondeprived adult $n g r 7^{f f / f f x} ;$ PV-Cre mice and after $1 \mathrm{~d} \mathrm{MD} .{ }^{* * *} p=0.0005$.

interneurons and the shift to a low PV network reports disinhibition of cortical circuitry.

\section{Discussion}

Here we demonstrate that the disinhibitory microcircuit initiating OD plasticity is confined to the critical period by ngrl operating in PV interneurons, and this disinhibition is accompanied by a decrease in the relative distribution of $\mathrm{PV}$ expression across this population of interneurons in visual cortex. These findings link the emerging circuit-level description of experience- dependent visual plasticity to the genetic regulation of the closure of the critical period.

How might ngrl restrict disinhibition and close the critical period? The molecular and cellular characterization of the NgR1 protein provides limited insight into potential mechanisms by which the receptor gates disinhibition. NgR1 is a neuronal receptor attached to the neuronal surface by a glycosylphosphatidylinisotol anchor, but the subcellular localization of $\mathrm{NgR} 1$ remains unclear, as the protein has been reported to be enriched in either dendritic spines or axons (Raiker et al., 2010; Zemmar et al., 2014; 
A

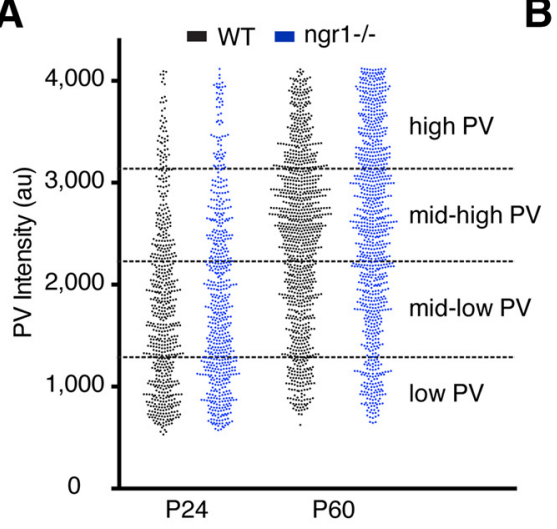

C

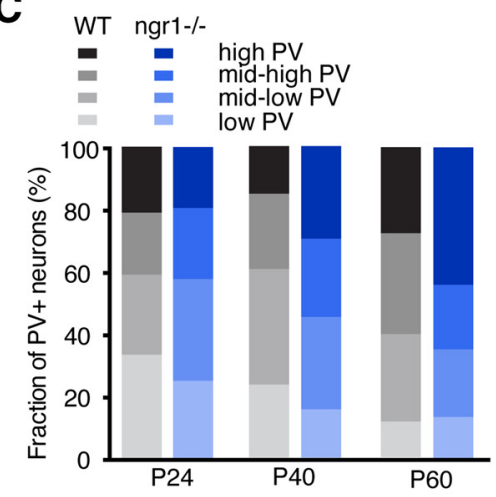

E

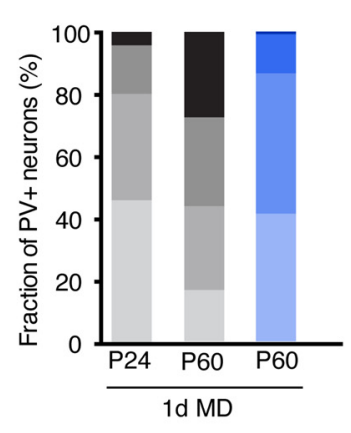

B

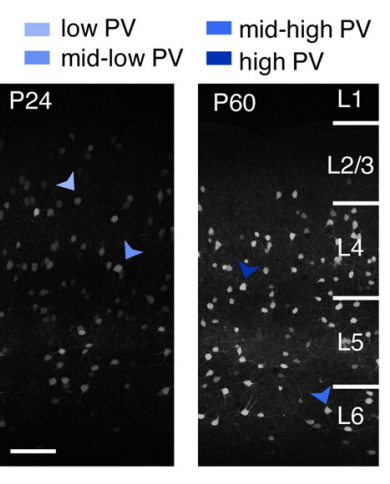

D

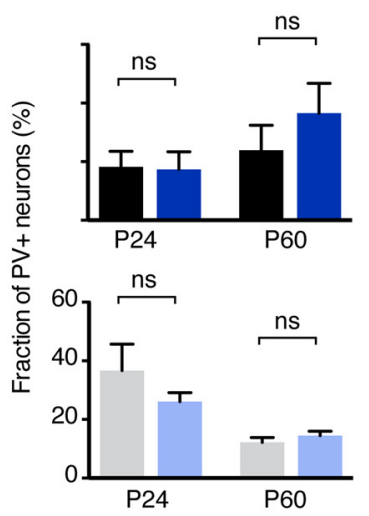

$\mathbf{F}$

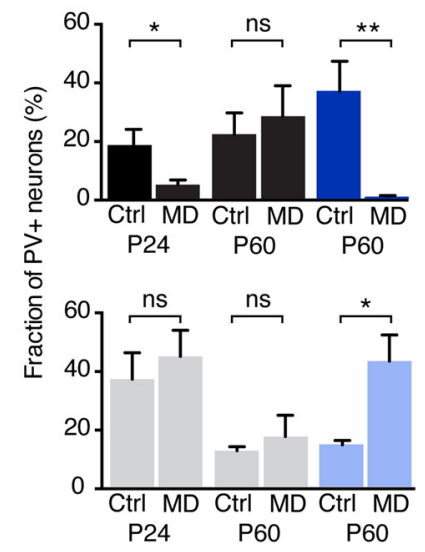

Figure 4. $\quad$ PV network configuration is altered by disinhibition in V1. $\boldsymbol{A}$, Representative population of PV intensities for one mouse from each age and genotype. Dots represent the intensity of one PV interneuron in arbitrary units (au). Dashed lines indicate the boundaries for expression level categories. $\boldsymbol{B}$, Immunostaining for PV in V1 of P24 and P60 ngr ${ }^{-1-}$ mice. C, Relative distribution of PV intensity in P24 ( $n=9$ and 8), P40 ( $n=6$ and 6$)$, and P60 $\left(n=7\right.$ and 5) WT and $n g r 1^{-1-}$ mice $(n=$ number of mice per group in parentheses). D, There is no significant difference in the fraction of PV neurons in the high- or low-PV configuration between WT and $n g r 1^{-1-}$ mice. $\boldsymbol{E}$, Relative distribution of PV intensity in P24 WT mice and P60 WT and $n g r 1^{-1-}$ mice with $1 \mathrm{~d}$ MD (MD). $\boldsymbol{F}$, The fraction of PV neurons in the high-PV configuration is lower with MD in P24 WT and in P60 ngr $1^{-/-}$ mice compared with age-matched nondeprived control mice (Ctrl), whereas the fraction of PV neurons in the low-PV configuration increases with MD. ${ }^{*} p<0.05 ;{ }^{* *} p<0.01$.

Stephany et al., 2015). NgR1 is expressed in visual cortex before eye opening ( P14), and expression levels are unchanged by the close of the critical period (McGee et al., 2005).

Recent studies have explored whether NgR1 limits the formation and stability of dendritic spines by excitatory pyramidal neurons. Unfortunately, these results do not support a unifying conclusion. Reducing the expression of NgR1 in transfected organotypic hippocampal cultures doubles dendritic spine density, whereas overexpressing NgR1 reduces spine density by half in vitro (Wills et al., 2012). However, spine density is normal in both $n g r 1^{-/-}$mice and transgenic mice overexpressing NgR1 (Lee et al., 2008; Karlén et al., 2009). Likewise, $n g r 1^{-1-}$ mice have been reported to display both dramatically elevated spine formation and new spine stability in vivo (Akbik et al., 2013). Yet we have performed similar, in some cases nearly identical, experiments with the same strain of $n g r 1^{-1-}$ mice, but we are unable to reproduce these findings. In our hands, the basal synaptic structural plasticity of $n g r 1^{-1-}$ is not different from WT mice (Park et al., 2014; Frantz et al., 2016). Experiments are still required to determine whether MD yields increased spine dynamics in $n g r 1^{-1-}$ mice beyond that reported for WT mice (Hofer et al., 2009). Yet, although ngrl is not a prominent regulator of basal synaptic turnover in adult brain, it may function in a more specific role to limit activitydependent and experience-dependent synaptic refinement.

As deleting ngrl selectively with PV-Cre is sufficient to permit the loss of excitatory synaptic input onto PV interneurons with MD in adult mice, NgR1 functions in these interneurons to stabilize excitatory synapses during the reduced overall cortical activity that induces disinhibition in V1 during the critical period. The distribution of ligands for NgR1, both myelin-associated proteins and chondroitin sulfate proteoglycans (CSPGs), increases as the critical period closes (Huang et al., 1999; McGee et al., 2005; Dickendesher et al., 2012). Interestingly, CSPGs are enriched in perineuronal nets that ensheath PV interneurons, and enzymatic digestion of sugar chains from CSPGs partially reactivates OD plasticity in rats (Pizzorusso et al., 2002). Perhaps NgR1 closes the critical period by interacting with CSPGs in perineuronal nets to stabilize excitatory synapses onto PV interneurons or counteract signaling pathways that promote disinhibition in visual cortex following $1 \mathrm{~d}$ MD.

Disinhibition is a conserved component of cortical plasticity that is implicated in associative learning and memory in hippocampus, amygdala, auditory cortex, and motor cortex (Letzkus et al., 2015). NgR1 is also expressed in these brain regions (Barrette et al., 2007). Moreover, transgenic overexpression of NgR1 disrupts hippocampal-dependent spatial learning (Karlén et al., 2009), whereas $n g r 1^{-1-}$ mice display aberrant extinction following auditory fear conditioning and a deficit in overall performance on the rotarod (Park et al., 2014). Whether ngrl also limits disinhibition in these neural circuits is not known. Future work will be required to determine how cortical circuits change during this transient period of elevated excitatory neurotransmission to yield the enduring alterations in 
cortical responsiveness associated with OD plasticity, a model of the prevalent childhood visual disorder amblyopia.

\section{References}

Akbik FV, Bhagat SM, Patel PR, Cafferty WB, Strittmatter SM (2013) Anatomical plasticity of adult brain is titrated by Nogo receptor 1 . Neuron 77:859-866. CrossRef Medline

Barrette B, Vallières N, Dubé M, Lacroix S (2007) Expression profile of receptors for myelin-associated inhibitors of axonal regeneration in the intact and injured mouse central nervous system. Mol Cell Neurosci 34: 519-538. CrossRef Medline

Deidda G, Allegra M, Cerri C, Naskar S, Bony G, Zunino G, Bozzi Y, Caleo M, Cancedda L (2015) Early depolarizing GABA controls critical-period plasticity in the rat visual cortex. Nat Neurosci 18:87-96. CrossRef Medline

Dickendesher TL, Baldwin KT, Mironova YA, Koriyama Y, Raiker SJ, Askew KL, Wood A, Geoffroy CG, Zheng B, Liepmann CD, Katagiri Y, Benowitz LI, Geller HM, Giger RJ (2012) NgR1 and NgR3 are receptors for chondroitin sulfate proteoglycans. Nat Neurosci 15:703-712. CrossRef Medline

Donato F, Rompani SB, Caroni P (2013) Parvalbumin-expressing basketcell network plasticity induced by experience regulates adult learning. Nature 504:272-276. CrossRef Medline

Donato F, Chowdhury A, Lahr M, Caroni P (2015) Early- and late-born parvalbumin basket cell subpopulations exhibiting distinct regulation and roles in learning. Neuron 85:770-786. CrossRef Medline

Fischer QS, Aleem S, Zhou H, Pham TA (2007a) Adult visual experience promotes recovery of primary visual cortex from long-term monocular deprivation. Learn Mem 14:573-580. CrossRef Medline

Fischer QS, Graves A, Evans S, Lickey ME, Pham TA (2007b) Monocular deprivation in adult mice alters visual acuity and single-unit activity. Learn Mem 14:277-286. CrossRef Medline

Frantz MG, Kast RJ, Dorton HM, Chapman KS, McGee AW (2016) Nogo receptor 1 limits ocular dominance plasticity but not turnover of axonal boutons in a model of amblyopia. Cereb Cortex 26:1975-1985. CrossRef Medline

Gandhi SP, Yanagawa Y, Stryker MP (2008) Delayed plasticity of inhibitory neurons in developing visual cortex. Proc Natl Acad Sci U S A 105:1679716802. CrossRef Medline

Gordon JA, Stryker MP (1996) Experience-dependent plasticity of binocular responses in the primary visual cortex of the mouse. J Neurosci 16 : 3274-3286. Medline

Harauzov A, Spolidoro M, DiCristo G, De Pasquale R, Cancedda L, Pizzorusso T, Viegi A, Berardi N, Maffei L (2010) Reducing intracortical inhibition in the adult visual cortex promotes ocular dominance plasticity. J Neurosci 30:361-371. CrossRef Medline

Hensch TK, Fagiolini M, Mataga N, Stryker MP, Baekkeskov S, Kash SF (1998) Local GABA circuit control of experience-dependent plasticity in developing visual cortex. Science 282:1504-1508. CrossRef Medline

Hippenmeyer S, Vrieseling E, Sigrist M, Portmann T, Laengle C, Ladle DR, Arber S (2005) A developmental switch in the response of DRG neurons to ETS transcription factor signaling. PLoS Biol 3:e159. CrossRef Medline

Hofer SB, Mrsic-Flogel TD, Bonhoeffer T, Hübener M (2009) Experience leaves a lasting structural trace in cortical circuits. Nature 457:313-317. CrossRef Medline

Huang ZJ, Kirkwood A, Pizzorusso T, Porciatti V, Morales B, Bear MF, Maffei L, Tonegawa S (1999) BDNF regulates the maturation of inhibition and the critical period of plasticity in mouse visual cortex. Cell 98:739-755. CrossRef Medline

Hubel DH, Wiesel TN (1970) The period of susceptibility to the physiological effects of unilateral eye closure in kittens. J Physiol 206:419-436. CrossRef Medline

Karlén A, Karlsson TE, Mattsson A, Lundströmer K, Codeluppi S, Pham TM, Bäckman CM, Ogren SO, Aberg E, Hoffman AF, Sherling MA, Lupica CR, Hoffer BJ, Spenger C, Josephson A, Brené S, Olson L (2009) Nogo receptor 1 regulates formation of lasting memories. Proc Natl Acad Sci U S A 106:20476-20481. CrossRef Medline

Kim JE, Liu BP, Park JH, Strittmatter SM (2004) Nogo-66 receptor prevents raphespinal and rubrospinal axon regeneration and limits functional recovery from spinal cord injury. Neuron 44:439-451. CrossRef Medline

Kuhlman SJ, Olivas ND, Tring E, Ikrar T, Xu X, Trachtenberg JT (2013) A disinhibitory microcircuit initiates critical-period plasticity in the visual cortex. Nature 501:543-546. CrossRef Medline

Lee H, Raiker SJ, Venkatesh K, Geary R, Robak LA, Zhang Y, Yeh HH, Shrager
P, Giger RJ (2008) Synaptic function for the Nogo-66 receptor NgR1: regulation of dendritic spine morphology and activity-dependent synaptic strength. J Neurosci 28:2753-2765. CrossRef Medline

Letzkus JJ, Wolff SB, Lüthi A (2015) Disinhibition, a circuit mechanism for associative learning and memory. Neuron 88:264-276. CrossRef Medline

Levelt CN, Hübener M (2012) Critical-period plasticity in the visual cortex. Annu Rev Neurosci 35:309-330. CrossRef Medline

Madisen L, Zwingman TA, Sunkin SM, Oh SW, Zariwala HA, Gu H, Ng LL, Palmiter RD, Hawrylycz MJ, Jones AR, Lein ES, Zeng H (2010) A robust and high-throughput Cre reporting and characterization system for the whole mouse brain. Nat Neurosci 13:133-140. CrossRef Medline

McGee AW, Yang Y, Fischer QS, Daw NW, Strittmatter SM (2005) Experience-driven plasticity of visual cortex limited by myelin and Nogo receptor. Science 309:2222-2226. CrossRef Medline

Morales B, Choi SY, Kirkwood A (2002) Dark rearing alters the development of GABAergic transmission in visual cortex. J Neurosci 22:80848090. Medline

Morishita H, Hensch TK (2008) Critical period revisited: impact on vision. Curr Opin Neurobiol 18:101-107. CrossRef Medline

Park JI, Frantz MG, Kast RJ, Chapman KS, Dorton HM, Stephany CÉ, Arnett MT, Herman DH, McGee AW (2014) Nogo receptor 1 limits tactile task performance independent of basal anatomical plasticity. PLoS One 9:e112678. CrossRef Medline

Pham TA, Graham SJ, Suzuki S, Barco A, Kandel ER, Gordon B, Lickey ME (2004) A semi-persistent adult ocular dominance plasticity in visual cortex is stabilized by activated CREB. Learn Mem 11:738-747. CrossRef Medline

Pizzorusso T, Medini P, Berardi N, Chierzi S, Fawcett JW, Maffei L (2002) Reactivation of ocular dominance plasticity in the adult visual cortex. Science 298:1248-1251. CrossRef Medline

Raiker SJ, Lee H, Baldwin KT, Duan Y, Shrager P, Giger RJ (2010) Oligodendrocyte-myelin glycoprotein and Nogo negatively regulate activity-dependent synaptic plasticity. J Neurosci 30:12432-12445. CrossRef Medline

Sato M, Stryker MP (2008) Distinctive features of adult ocular dominance plasticity. J Neurosci 28:10278-10286. CrossRef Medline

Sawtell NB, Frenkel MY, Philpot BD, Nakazawa K, Tonegawa S, Bear MF (2003) NMDA receptor-dependent ocular dominance plasticity in adult visual cortex. Neuron 38:977-985. CrossRef Medline

Shepherd GM, Pologruto TA, Svoboda K (2003) Circuit analysis of experience-dependent plasticity in the developing rat barrel cortex. Neuron 38:277-289. CrossRef Medline

Stephany CÉ, Chan LL, Parivash SN, Dorton HM, Piechowicz M, Qiu S, McGee AW (2014) Plasticity of binocularity and visual acuity are differentially limited by Nogo receptor. J Neurosci 34:11631-11640. CrossRef Medline

Stephany CÉ, Frantz MG, McGee AW (2015) Multiple roles for Nogo receptor 1 in visual system plasticity. Neuroscientist. Advance online publication. Retrieved Nov. 9, 2015. doi: 10.1177/1073858415614564. CrossRef Medline

Taha S, Hanover JL, Silva AJ, Stryker MP (2002) Autophosphorylation of alphaCaMKII is required for ocular dominance plasticity. Neuron 36: 483-491. CrossRef Medline

Wang X, Duffy P, McGee AW, Hasan O, Gould G, Tu N, Harel NY, Huang Y, Carson RE, Weinzimmer D, Ropchan J, Benowitz LI, Cafferty WB, Strittmatter SM (2011) Recovery from chronic spinal cord contusion after Nogo receptor intervention. Ann Neurol 70:805-821. CrossRef Medline

Weiler N, Wood L, Yu J, Solla SA, Shepherd GM (2008) Top-down laminar organization of the excitatory network in motor cortex. Nat Neurosci 11:360-366. CrossRef Medline

Wiesel TN, Hubel DH (1963) Single-cell responses in striate cortex of kittens deprived of vision in one eye. J Neurophysiol 26:1003-1017. Medline

Wills ZP, Mandel-Brehm C, Mardinly AR, McCord AE, Giger RJ, Greenberg ME (2012) The Nogo receptor family restricts synapse number in the developing hippocampus. Neuron 73:466-481. CrossRef Medline

Xu X, Olivas ND, Levi R, Ikrar T, Nenadic Z (2010) High precision and fast functional mapping of cortical circuitry through a novel combination of voltage sensitive dye imaging and laser scanning photostimulation. J Neurophysiol 103:2301-2312. CrossRef Medline

Zemmar A, Weinmann O, Kellner Y, Yu X, Vicente R, Gullo M, Kasper H, Lussi K, Ristic Z, Luft AR, Rioult-Pedotti M, Zuo Y, Zagrebelsky M, Schwab ME (2014) Neutralization of Nogo-A enhances synaptic plasticity in the rodent motor cortex and improves motor learning in vivo. J Neurosci 34:8685-8698. CrossRef Medline 